\title{
Pronoun, Personal Titles, and Variety of Java-Indonesian Language in Yowis Ben The Series Film: Contrastive Study
}

\author{
Yustri Agung Prastiyono ${ }^{*}$, Yacub Fahmilda ${ }^{2}$, Suryawahyuni Latief ${ }^{3}$ \\ 1,2 Universitas Gadjah Mada, Indonesia \\ 3 Universitas Nurdin Hamzah Jambi, Indonesia
}

Yustri.a@mail.ugm.ac.id*

\begin{tabular}{l} 
Abstract \\
\hline This study aimed to identify and to contrast differences in Javanese- \\
Indonesian speech acts in the Yowis Ben The Series film. This study used a \\
contrastive analysis study with a sociolinguistic approach, which in this \\
context emphasizes the aspects of pronouns, personal titles, and language \\
variations. The method used in this research was descriptive qualitative. The \\
data in this study are speech acts in Javanese and Indonesian (translation) \\
which are used as dialogues in the film. The data source in this study was \\
taken from the Yowis Ben The Series film through the WeTV video streaming \\
application. The results of this study indicated that there were differences \\
usage of Javanese-Indonesian speech in aspects of pronouns, personal titles, \\
and language variations. This difference was due to non-linguistic aspects, \\
such as the speaker's background, age, position or degree of speech partners \\
in society.
\end{tabular}

\author{
ARTICLE INFO \\ Article history: \\ Received \\ March 27, 2021 \\ Revised \\ April 12, 2021 \\ Accepted \\ April 17, 2021
}

How to cite

Keywords: Speech Act, Contrastive Analysis, Sociolinguistic

Prastiyono, Y., Fahmida, Y., \& Latief, S., (2021). Pronoun, Personal Titles, and Variety of Java-Indonesian Language in Yowis Ben The Series Film: Contrastive Study. Anglophile Journal, 1(2).p.32-41.

https://dx.doi.org/10.51278/anglophile.v1i2.228

This is an open access article under the CC BY SA license

https://creativecommons.org/licenses/by-sa/4.0/

Published by

\section{INTRODUCTION}

Language is the most important aspect of human life. Through language, humans can form and understand culture in society. In this connection, Anderson in Tarigan (2009) argues that the essence of language is a means of communication. Furthermore, Brown in Tarigan (2009) also argues that the essence of language is not just a means of communication but a system consisting of a set of symbols (vocals or visuals) which have conventional meanings. From this explanation, it can be concluded that language is a system consisting of symbols (vocals or visuals) containing certain information or meanings that present and play a role in the formation of culture in the community.

Over time, languages develop according to their respective environments. Basically, language has formed a peculiarity in various existing cultures. As a result, language developed rapidly and was considered an identity to mark the culture of a particular society. For example, Javanese language is closely related to Indonesian. Javanese is a local language that is growing rapidly on the island of Java, while Indonesian is the national language that comes from the Malay language family. Even though they have different positions in their usage, they both have similarities because in the process of development, Indonesian vocabulary is largely absorbed from Javanese. Furthermore, the fundamental difference between Javanese-Indonesian is that there is a speech level in Javanese which can be categorized as a variety of $n g o k o(\mathrm{Ng}=$ coarse $)$, madya variety $(\mathrm{Kl}=$ medium), and variety of krama $(\mathrm{Ki}=$ polite $)$. Notice the example below. 
[Ng] 'Kowe'

[Kl] 'Sampeyan'

[Ki] 'Panjenengan'
: kamu (the pronoun 'you' is used while speak to friend, mate, and an older speaks to young)

: kamu (pronoun 'you' is used while speak to stranger or to a person first met )

: kamu (pronoun 'you' is used while a younger speaks to parents/older ones and the low position of person speaks to higher position in an employment, company, and society)

In addition regarding of these speech levels, Javanese language also has many varieties of dialects in each of its distribution areas, for example.

'Kowe' : kamu (Region of Central Java Province, borderline province of East Java -Central Java, Yogyakarta)

'Koen' : kamu (Region of Surabaya, Malang, and its surrounding)

'Riko' : : kamu (Region of Banyuwangi, the east part of East Java Province)

In everyday life, the use of this language, both Indonesian and Javanese, appears through various in written and spoken means. In written means, the use of language can be found in newspapers, books, social media, etc. Furthermore, the use of language in spoken means can be found in radio, podcasts, instructional videos, plays, speeches, sermons, films, etc. From these various means, the film is considered to be able to contain complete information about the use of language because the audience can witness the creation of speeches from a combination of sound and visuals simultaneously.

According to KBBI, the film is defined as a device in the form of a thin membrane made of celluloid to place negative images (which will be made portraits) or to place positive images (to be played in theaters). Himawan in Agustina \& Pristiwati (2019) argues that film is a combination of audio and visual. The film can also be interpreted as a reflection of the cultural phenomenon of the community concerned, in this case, the film is the same as literary works.

To find out the difference in the use of speech acts between Javanese-Indonesian in Yowis Ben The Series, a contrastive analysis study is used by applying a sociolinguistic approach. In this study, the sociolinguistic aspects of language studied were the use of pronouns, personal titles, and language speech levels. Previously, Kridalaksana in Hermanto (2015) stated that contrastive analysis is a language analysis to find out the similarities and differences between languages and dialects which is aimed to be applied in language teaching or translation. Furthermore, Tarigan in Hermanto (2015) also says that contrastive analysis is an activity to compare the structure of B1 to B2 which aims to reveal the differences between the two languages.

As Fauziati (2014) said that Charles C. Fries is the initiator of the first contrastive analysis saying that the most effective language learning materials are descriptions of two languages that are parallel compared to the learners' mother tongue. According to AlKhresheh's (2016) view, contrastive analysis can be understood as three approaches. First, it becomes a pure linguistic approach to contrasting two languages so that new science can be found. Second, it becomes a practical approach in language teaching so that errors, similarities and differences are found between the target language and the mother tongue (Dost, I. N., \& Bohloulzadeh, G. 2017). Third, it has a position as a degraded approach to language learning compared to the past because it does not have legitimacy in the universal scheme of language teaching.

Wijana (2011) defines sociolinguistics as a derivative of linguistics that studies the relationship of a language with the social factors of its speakers. In line with this theory, Fishman in Rokhman (2013) reveals that sociolinguistics is a study of language that deals with the actual use of language such as dialects in certain cultures. Furthermore, Dickey in Rokhman (2013) states that sociolinguistics is a study to determine the use of language in a society that has certain rules. The language usage that forming the rules because of these 
social factors creates variations or types of language. Sociolinguistically, the emergence of language variations is caused by various linguistic factors at various levels, such as phonology, grammar (morphology and syntax), and lexicon (Wijana, 2011).

Alwi et al., (2003) argue that the variety of languages can affect the attitudes of speakers because speaking is influenced by speech partners and the things being discussed. The attitudes of speakers are influenced by the age and position of the speech partners, the level of intimacy between the speakers, the subject matter, and the purpose of conveying information. Thus, it can be concluded that sociolinguistics is the study of language by paying attention to aspects outside of language, such as speaker's background, age, and speech situations.

In practical terms, contrastive research have implications for the enrichment of linguistics. Based on the utterance of Khobadandeh (2007) the results of research with linguistic contrast analysis can be used for teaching translation. Khobadandeh (2007) also adds that teachers who have this knowledge can understand problems as well as provide solutions in their teaching. On the other hand, learning Indonesian and Chinese faces some difficulties because the two languages are rooted in different language families (Sadeghi, S., \& Mowlaie, B. 2018). The case study researched by Widodo and Xiao (2019) is the use of particles from both languages. Contrastive analysis plays a role in parsing the problems related to particles in both languages by knowing the similarities and differences. Advances in technology bring global and borderless language and cultural interactions with implications for an increase in the number of speakers who learn languages other than their mother tongue (Sumiati and Marliasari, 2018). This can also be seen in the phenomenon of Indonesian native speakers who master more than 2 languages, namely in addition to Indonesian and regional languages. On the other hand, non-Indonesian native speakers also learn Indonesian and regional languages. Some of these foreign speakers also show-up on social media platforms such as LondoKampung.

This study aimed to identify and to contrast the differences in Javanese-Indonesian speech acts in the "Yowis Ben The Series" film. The data in this study came from the Indonesian drama-comedy film series entitled Yowis Ben: The Series. This series officially released on September 18, 2020, is also a prequel to two previously released films. This film is played by Bayu Eko Moektito (Bayu Skak), Brandon Salim, Joshua Suherman, and Tutus Thomson. This chosen film as the object of research is due to in scene two mixed languages are used, namely Indonesian and Javanese with a typical dialect of Malang, East Java.

\section{METHODS}

The data source in this study is the Yowis Ben The Series film, which has been broadcast since 2020 through the WeTV video streaming application. The data in this study are speech acts in Javanese and Indonesian (translation) which are used as dialogues in the film. Furthermore, in data collection, the technique of engaging free listening proficient (Simak Bebas Libat Cakap) and note-taking technique was used. According to Zaim (2014) the technique of engaging free listening proficiently (Simak Bebas Libat Cakap) allows researchers not to engage in conversation and listen to what is being said. Then proceed with the note-taking technique (Kesuma, 2007), which is capturing data by recording the results of the observation on paper or a document recording application.

Qualitative descriptive research method is used to analyze data in the form of speeches obtained after going through the data collection process. Descriptive qualitative analysis techniques can provide an explanation of the contrasting of meanings in JavaneseIndonesian speech acts used in the film. The steps taken in data analysis are as follows.

(1). The data were obtained through listening and recording of the stories in the Yowis Ben The Series film 
(2). The data is displayed in Javanese-Indonesian and then classified into pronouns, personal titles, and language variations.

(3). The data were then analyzed using a qualitative descriptive method to determine the differences between the two languages.

\section{RESULT AND DISCUSSION \\ Pronoun}

Alwi in (Muhidin, 2017) said that pronoun can occupy the position of the subject and object in a sentence. Chaer in (Muhidin, 2017) states that a pronoun is a noun that states a person and is referring a person by using other term. On the other hand, Alwi et al (2003) etiquette that is integrated in social life affects the use of personal pronouns which are generally related to three parameters, those are (1) age, (2) social status, (3) intimacy. Data (1) Context: Cak Jon chats together with Rini at a cafe.
Rini
: "Mas Jon!..."
Mas/Jon
Cak Jon
: "Yo dik..."
Iya/ dik
Rini
: "Sesuk awakdewe sido nang Suroboyo kanggo ngurusi pernikahan?"
Cak Jon Besok/ kita/jadi/ ke/ Surabaya/ untuk/ mengurus/ pernikahan?

$$
\text { : "Yo sido dik!..." }
$$$$
\text { Iya/ jadi/ dik! }
$$

Data (1) shows the use of the Javanese pronoun, the term awakdewe, which in Indonesian means kita (english: we/us). The use of the word awakdewe in Javanese occurs between equal and familiar speakers. In this context, the character Rini is narrated to have a close relationship with the character Cak Jon (lover relationship). This is different from the use of kita (english: we/us) in Indonesian which are more commonly used without the need to pay attention to differences in backgrounds between speakers and speech partners. Moreover, kita (english: we/us) in Indonesian is more inclusive referring to the situation between speaker and hearer.

Data (2) Context: Bayu, Cak Kartolo \& Cak Wito, Aliya are having breakfast in the Warung Ibu Bayu.

Bayu

Cak Kartolo \& Cak Wito

Bayu

Cak Cak Wito

Bayu

Cak Wito

Bayu

Cak Wito

Bayu

Cak Kartolo
: “Cak Kartolo, Cak Wito!”

Cak Kartolo/ Cak Wito!

$$
\text { : “Opo?” }
$$$$
\text { Apa? }
$$

: "Sanjange wingi sakit?"

Katanya/ kemarin/ sakit?

: "Iyo aku loro, Yu"

Iya/ aku/ sakit

: "Sakit nopo?"

Sakit/ apa?

: "Jare dokter kakean pikiran"

Kata/ dokter/ kebanyakan/ pikiran

: "Mikiri nopo?"

Memikirkan/ apa?

: "Mikiri ibukmu, Yu!"

Memikirkan/ibumu/Yu!

: "Nek, njenengan Cak Kartolo, sampun teng dokter?"

Kalau/anda/Cak Kartolo/ sudah/ ke/ dokter?

: "uwis obate ndek kene jare!"

Sudah/ obatnya/ disini/ katanya! 
Ibu Bayu

Cak Kartolo

In data (2), there are two uses

: "Opo Cak, pecel?"

Apa/ pak/Nasi pecel?

: "Yo Sampeyan iku!"

Ya/kamu/ itu! njenengan or panjenengan as Anda for Indonesian (english: you) and the word sampeyan as Kamu for Indonesian (english: you). The two pronouns, panjenengan and sampeyan have the same meaning, but differ in function and position. The pronoun njenengan or panjenengan is a variety of krama (Ki) which is used in speech between younger people and older people. In this context, Tokoh Bayu (still in high school) tells the character of Cak Kartolo (the same age as Ibu Bayu). Conversely, the use of the pronoun sampeyan is the intermediate variety ( $\mathrm{Kl}$ : krama madya) used in speech between an older person and a younger person or equivalent. In this context, the character Cak Kartolo tells Ibu Bayu, both of whom are equal in terms of age.

In Indonesian, it is known that the pronoun Kamu (english: you) is used between speakers and speech partners with the same age or equivalent. Meanwhile, the use of pronoun Anda (english: you) occurs between speakers of a lower position than the speech partner or in a formal / official context.

\section{Personal Titles}

Kridalaksana in (Pratama, 2018) defines personal titles as a system that connects a set of words or expressions used to refer to or call the actors in ongoing communication. Furthermore, Nababan in (Pratama, 2018) revealed that the use of personal titles for each community group is different from other groups because the personal titles reflects the cultural and social structure of the related community groups.

Alwi et al (2003) say that for culture and ethnicity in Indonesia, the use of second personal pronouns, such as Kamu, Anda, and Engkau (english : you) are considered less respectful so that the term kinship is used, such as Bapak (english: Mr/Sir), Ibu (english: Madame, Mrs), Saudara, Kakak, and Adik (english: brother). However, in Javanese, kinship terms such as Mas and Mbak are also used. In connection with this theory, it is found in data 3 and 4 as follows.

Data (3) Context: Cak Jon went home after calling off his travel to Surabaya.

Ibu Bayu

: "Yo opo ta Jon, kok malah pithike sing dikongkon nang Suroboyo?"

Bagaimana/Jon/kenapa/ayamnya/yang/disuruh/ke/Surabaya?

Cak Jon

: "Atiku durung tetep mbak!"

Hatiku/ belum/ mantap/kak!

Ibu Bayu

: "Saiki mantepno atimu!"

Cak Jon

Sekarang/ mantapkan/ hatimu!

: "Iyo, mbak"

Iya/kak

In data (3) there is a use of the Javanese personal titles, namely the word Mbak (english: miss/elde Sister) which means older sister in Indonesian. In Javanese, the address for older sister is called Mbak while older brother is called Mas. According to Zakiyah (2018), the personal titles Mas comes from the Javanese language which means as the son of a Kiai who is still a child in the social sphere of the pesantren. Zakiyah (2018) adds in his study that mas can also be equivalent to the personal titles of Gus because it comes from the word Kangmas, which is a combination of Kang and Mas. In terms of taste and function of language, the two addresses differ in the scope of the pesantren. In pesantren, Mas is used to refer to a Kiai's young son or siblings.

Data (4) Context: Pak Ustadz is chatting with Mia in front of the perfume store while Rini comes and cries. 
Pak Ustadz : "Jarene wis budhal Suroboyo, kok mbalik maneh. Ono opo to Rin?" Katanya/sudah/berangkat/ke/Surabaya/kok/pulang/lagi/Ada/apa/Rin?

Rini : "Mboten sido, kulo mboten ngertos karepe Mas Jon niki nopo! Tidak/ jadi/ saya/ tidak/ tahu/ kemauannya/Mas Jon/ itu/ apa! Pun kulo lakoni mbolak balik Suroboyo-Malang. Sudah/saya/lakukan/pulang/pergi/Surabaya-Malang. Nanging kulo koyo dolanan." tetapi/saya/ seperti/mainan

Pak Ustadz : "Sabar Rin!" Sabar/ Rin

Rini : : "Paklik, lek pancen ora jodoh yo ojo koyo ngene to!" Paman/ kalo/ memang/ bukan/ jodoh/ tolong/ jangan/ seperti/ ini

Pak Ustadz : "He he he, ojo ngomong ngunu ta, ndak ilok sing penting ndungo!" Hehehe/jangan/bicara/seperti/itu/tidak/sopan/yang/penting/berdoalah

In data (4) there is a use of personal titles in Javanese, namely Mas (english: brother/elde brother) and Paklik (english: uncle). The word Mas in Indonesian is defined as a man who is older than the speaker whether there is a relative or not. Meanwhile, the word Paklik in Indonesian is used as a personal titles to the younger brother of the mother or father or called uncle.

Zakiyah's research (2018) in the scope of pesantren (Islamic boarding schools) in Jombang Regency, East Java Province, the personal titles Cak is a special greeting that comes from the Javanese language. The personal titles of Cak is used by members of the pesantren to be among the students, on a parallel with Kang and Mbak. In the social context of pesantren, the word Cak is not parallel to the personal titles of Gus, which refers to the Kiai's adult son. However, the word Cak is also found in this film. Here are the data.

Data (5) Context: Bayu, Cak Kartolo \& Cak Wito, Aliya are having breakfast in Warung Ibu Bayu

Bayu

: “Cak Kartolo, Cak Wito!”

Cak Kartolo/Cak Wito!

Cak Kartolo \& Cak Wito

: “Opo?”

Apa?

Bayu

: "Sanjange wingi sakit?"

Katanya/ kemarin/ sakit?

Cak Cak Wito

: "Iyo aku loro, Yu"

Iya/ aku/ sakit

Data (5) shows the use of the Javanese personal titles that is Cak. The word Cak in this context is defined as a designation for a man who is considered older or elder. In connection with this research, the personal titles of Cak is used as a sign that speakers and speech partners have a background in the same social structure in the wider community. Moreover, this personal titles is used more frequently in East Java than in Central Java and Yogyakarta, which use Mas more often.

\section{Variety of languages}

Kartomihardjo in Rokhman (2013) states that variety is a tool to convey social meanings that cannot be conveyed through words with literal meanings. Furthermore, that variety is a variation of language with different usage according to the topic being discussed (Melnyk, 2019). In the context of this research, the variety meant is the level (speech level) in Javanese, namely the variety of ngoko ( $\mathrm{Ng}=$ coarse), the variety of madya $(\mathrm{Kl}=$ medium), and the variety of krama $(\mathrm{Ki}=$ polite $)$.

Data (6) Context: Pak Ustadz is chatting with Mia in front of the parfume store while Rini comes and cries. 
Pak Ustadz : "Jarene wis budhal Suroboyo, kok mbalik maneh. Ono opo to Rin?" Katanya/sudah/berangkat/ke/Surabaya/kok/pulang/lagi/Ada/apa/Rin?

Rini : :Mboten sido, kula mboten ngertos karepe Mas Jon niki nopo! Tidak/ jadi/aku/ tidak/ tahu/ maunya/ Mas Jon/ itu/ apa/ Pun kula lakoni mbolak balik Suroboyo-Malang. Sudah/aku/ lakukan/ pulang/ pergi/ Surabaya-Malang Nanging kula koyo dolanan." tetapi/aku/ seperti/ mainan

Pak Ustadz : "Sabar Rin!”

Sabar/ Rin

In data (6) there is a variety use in Javanese, namely the word Kula which means Aku (english: I/me) in Indonesian. There are several types of word levels to refer Aku (english: $\mathrm{I} / \mathrm{me}$ ) in Javanese, namely $\mathrm{Aku}$ (variety ngoko $=\mathrm{Ng}$ ), kula (variety medium $=\mathrm{Kl}$ ), and kawula, abdi, dalem (variety krama $=\mathrm{Ki}$ ).

Data (7) Context: Bayu and Doni come to Pak Ustadz while he is sittin inside mosque.

Bayu \& Doni : Ngapunten Pak Ustadz, wau kula badhe tanglet, pripun pak?

Permisi/ Pak Ustadz/ tadi/ saya/ mau/ bertanya/ bagaimana pak

Pak Ustadz : Oh,, iyo-iyo sik, tapi sak durunge iku aku tak takon, oh/ iya-iya/ sebentar/ tapi/ sebelumnya/ aku/ mau/ bertanya/ awakmu kabeh pingin oleh pahala? kalian/ semua/ ingin/ mendapat/ pahala

Bayu \& Doni : Purun, Pak! mau/ Pak

In data (7), the variety of languages is indicated by the use of Kula in Javanese as an variety of madya $(\mathrm{Kl})$ which in this context is defined as Saya in Indonesian (english: I/me). The chosen meaning of Saya (english: I/me) compared to Aku (english: I/me) is due to the background factor of the partner's speech. In this context, speech partners have a social status in the community so that Saya (english: I/me) usage is considered more polite than Aku(english: I/me). Meanwhile, the speech partner uses the word Aku (english: I/me) in reply to a conversation which indicates the use of the ngoko variety ( $\mathrm{Ng}=$ coarse $)$.

\section{DISSCUSSION}

The main findings of this study are nonlinguistic aspects that influence the use of East Javanese and Indonesian languages. There were differences in the concept of plural first-person pronouns in Indonesian and Javanese. In addition, this is found similarities in the concept of a singular second person pronoun in Indonesian and Javanese. The use of pronouns depends on age, social relationship, social position between the speaker and the speech partner. Meanwhile, there are differences and similarities in personal titles in Javanese and Indonesian. This difference is due to the geographical dialect aspect of East Java in the use of the words Cak and Paklik which do not exist in Indonesian and the Javanese dialect of the provinces of Central Java, the borderline of East Java - Central Java, and Yogyakarta. However, there are similarities in the use of the words Mas and Mbak in Javanese and Indonesian. In language variations, Javanese and Indonesian have something in common. The similarity is the concept of using pronouns based on age, social status, and situation. In Javanese it is known as the speech level but in Indonesian it is called the level of politeness and the variety as formal languages.

The novelty in this research is found in the material object in the form of speech in the film and the result of the contrast description of Javanese - Indonesian language. Widodo and Xiao's research (2019) contrasts Indonesian with Chinese, especially in the use of particles from both languages. Sulaiman's (2018) research on pronouns only focuses on contrasting the use of third person pronouns in Indonesian and English. 
Meanwhile, current research has focused on first-person plural and second-person singular. Even though Wulandari (2017) examined the word personal title, it was found that there were differences in personal titles in Sundanese and Japanese compared to Javanese and Indonesian. This departs from the concept of using names in Japan which is different from that in Indonesia, especially Javanese and Sundanese. In Japanese it is known as the first name and last name or family name, while in Indonesia it does not have a family name. Meanwhile, the use of personal titles in Indonesia is more general with the personal title of relatives and gender, such as Pak, Bapak, Bu, Ibu, Mas, and Mbak.

This research on the contrast of Javanese and Indonesian pronouns shows the differences in pronouns in English and Arabic based on research by Zainuddin (2015). In English and Arabic, pronouns are used based on gender. However, pronouns in Javanese and Indonesian are based on age, social status, and social closeness. This is because the Javanese and Indonesian languages do not use the concept of gender in pronouns.

The material object of this study is different from previous research conducted by Khobadandeh (2007). The data from this study were obtained from the Yowis Ben The Series film telling which uses Javanese and Indonesian languages. Meanwhile, data from Khobadandeh's research (2007) comes from online newspaper headlines in English and Persian. In practical terms, Khobadandeh's research (2007) has implications for teaching Persian and English journalistic language. Meanwhile, the contrastive analysis of this film has implications for people's understanding of polite language when speaking in Javanese and Indonesian. Thus, contrastive studies are not limited to the similarities and differences in working language systems but can be used to understand the concept of language speakers' politeness.

The use of contrastive theory in this study is both a reinforcement and a reformer of the study of contrastive theory by Al-Khresheh (2016). According to Al Khresheh (2016), contrastive linguistic studies have implications for language teaching which can analyze barriers and alternatives to learning the target language. However, this contrasting study of Javanese and Indonesian speech of the film did not find this case. This is because this study focuses more on contrasting descriptions of Javanese and Indonesian in the film. Moreover, this study reveals that every language has a system of use related to nonlinguistic aspects such as age, social status, and social closeness. Thus, this contrasting theory can be used in understanding the world view of a society in relation to a very situational variety of languages.

Al-khresheh's theory (2016) is in line with Fauziati (2014) which examines the concept of contrastive analysis. The use of contrastive analysis is used to make target language learning successful through language system descriptions, student language errors, and student language error hypotheses (Widodo and Xiao, 2019; Al-khresheh, 2016; Fauziati, 2014; Amini, R., \& Bayesteh, 2020). On the other hand, the material object of a speech in this film shows nonlinguistic aspects, namely those related to social and cultural aspects. Through this research on film speech, it is also found the similarities and differences in the use of personal pronouns, personal titles, and various languages. Moreover, this research can also reveal societal aspects that influence language use.

Based on the results of the discussion above, this research contributes both theoretically and practically. Theoretically, this research increase knowledge and assessment of contrastive linguistics which consider social or nonlinguistic aspects. Practically, this research can be used as a reference for learning Indonesian and Javanese for foreign speakers because it is written in English. Moreover, it can also be used for social science in general to understand society based on linguistic phenomena. This is because there are similarities and differences in the social aspects of the use of Javanese and Indonesian. 


\section{CONCLUSION}

Based on the results of the analysis above, it can be concluded that there is a difference between the use of Javanese and Indonesian in the Yowis Ben The Series film. These differences include (1) in the pronoun aspect, the use of awakdewe (ind: kita, eng: we/us), panjenengan (ind: Anda, eng: you), sampeyan (ind: kamu, eng: you) is found. (2) in the aspect of address or personal titles, the words Mbak (older sister), Mas (older brother), Cak (uncle in the East Javanese dialect) are found, Paklik (uncle in the madya variety). (3) in the aspect of language variety, the words kula (saya of the madya variety), panjenengan (Anda of the krama variety), sampeyan (kamu of the madya variety), awakmu or kowe (kamu of the ngoko variety) are found. The results of the presentation prove that there is a difference between the use of Javanese and Indonesian which is related to the background of the speakers, age, position or degree of speech partners in society.

\section{ACKNOWLEDGEMENTS}

This research is the assignment of the Contrastive Linguistics class which is supervised by Prof. I Dewa Putu Wijana. He is a professor of linguistics from the Indonesian Language and Literature program, Gadjah Mada University, Indonesia. He has published many books and research articles on linguistics. Through his class, the first writer is grateful for the knowledge that can ultimately contribute to science, especially the Javanese - Indonesian contrastive linguistics. The first author also thanks Yacub Fahmilda as the second writer who worked together remotely during the pandemic so that he was able to complete and publish this paper. Through this publication, we as the first and second authors understand that in the midst of the limitations of this pandemic everyone can still contribute based on their role in society

\section{AUTHORS CONTRIBUTION STATEMENT}

This research is expected to be useful theoretically and practically. In the theoretical field, this research can complement the research treasures of Indonesian and regional languages, especially Javanese. In practical terms, the results of this study can be used as an overview for foreign speakers who want to learn the use of Javanese or Indonesian because they are published in English. The benefit is further strengthened because in this film is used as a "prototype" for the occurrence of linguistic phenomena in everyday life so that readers more easily understand the practice of using language in the field.

\section{REFERENCES}

Agustina, N., \& Pristiwati, R. (2019). Pelanggaran Prinsip Kesantunan Dalam Film Yowis Ben Karya Bayu Skak. Jurnal Profesi Keguruan, 5(2), 162-168. Google Scholar

Al-khresheh, M. H. (2016). A Review study of contrastive analysis theory. Journal of Advances in Humanities and Social Sciences, 2(6), 330 - 338. Google Scholar

Amini, R., \& Bayesteh, J. (2020). Investigating error analysis in interlinguistic English language teaching and the consequences of contradictory analysis on teaching quality. Journal of Humanities Insights, 4(02), 76-81. https://dx.doi.org/10.22034/jhi.2020.109840

Alwi, H., et al. (2003). Tata Bahasa Baku Bahasa Indonesia. Edisi Ketiga. Balai Pustaka: Jakarta.

Dost, I. N., \& Bohloulzadeh, G. (2017). A review of contrastive analysis hypothesis with a phonological and syntactical view: a cross-linguistic study. The Buckingham Journal of language and linguistics, 10, 32-41. https://doi.org/10.5750/bjll.v10i0.1482

Fauziati, E. (2014). Contrastive Analysis, Transfer Analysis, Error Analysis and Interlanguage: Four Concepts One Goal. Ahmad Dahlan Journal of English Studies, 1 (2), 9 - 21. Google Scholar 
Hermanto, A. B. (2015). Analisis Kontrastif Afiksasi Verba Bahasa Jawa dengan Bahasa Indonesia. Medan Makna, 13(1), 1-12. Google Scholar

Kesuma, T. M. J. (2007). Pengantar (Metode) Penelitian Bahasa. Penerbit Carasvatibooks: Yogyakarta.

Khodabandeh, F. (2007). A Contrastive Analysis of English and Persian Newspaper Headlines. Linguistics Journal, 2 (1), 91-127. Google Scholar

Marliasari, S. dan Sumiati. (2018). A Contrastive Analysis of Suffixes between English and Uzbek Languages. Channing: English Language Education and Literature, 3(2), 60-69. https://doi.org/10.30599/channing.v3i2.465

Melnyk, N. (2019). Sociolinguistics studies of English language: analytical overview of the problem. Science and Education a New Dimension. Philology VII (63), (212), 36-40. Google Translate

Muhidin, R. (2017). Pronomina Bahasa Jawa Dialek Banyumas di Kota Pangkal Pinang. Kelasa, 12(1), 95-112.

Pratama, N. (2018). Sapaan dalam Bahasa Dayak Tomun di Desa Sekoban, Kecamatan Lamandau, Kabupaten Lamandau, Provinsi Kalimantan Tengah. Sintesis, 12(2), 8290. Google Scholar

Rokhman, F. (2013). Sosiolinguistik: Suatu Pendekatan Pembelajaran Bahasa dalam Masyarakat Multikultural. Graha Ilmu.

Sadeghi, S., \& Mowlaie, B. (2018). Contrastive Analysis of Political News Headlines Translation According to Berman's Deformative Forces. Journal of Language and Translation, 8(3), 29-41. Google Scholar

Sulaiman, M. (2018). A contrastive analysis between english and indonesian pronominals. English Empower: Journal of Linguistics and Literature, 3(2), 82-91. Google Scholar

Tarigan, H. G. (2009). Pengajaran Pragmatik (T. P. Angkasa (ed.); Edisi Revisi). Angkasa.

Tatuta, Syane. (2017). Sapaan kekerabatan dalam bahasa inggris dan bahasa biak: suatu analisis kontrastiF. Skripsi. Universitas Sam Ratulangi. Google Scholar

Widodo, P. dan Xiao Q. (2019). Contrastive Analysis of Particles in Chinese and Indonesian Language. LITERA, 18 (3), 361 - 378. Google Scholar

Wijana, I D. P. (2011). Berkenalan dengan Linguistik. ACom Press : Yogyakarta.

Wulandari, Suci Asri. (2017). Analisis kontrastif kata sapaan dalam bahasa jepang dan bahasa sunda. Skripsi. Universitas Pendidikan Indonesia. Google Scholar

Zaim, M. (2014). Metode Penelitian Bahasa: Pendekatan Struktural (Ermanto (ed.)). FBS UNP Press Padang. Google Scholar

Zainuddin. (2015). A contrastive analysis between personal pronoun in english and arabic language. Jurnal English Education, 2 (3), 128-139. https://doi.org/10.24952/ee.v3i02.1211

Zakiyah, M. (2018). Makna Sapaan di Pesantren: Kajian Linguistik-Antropologis. Jurnal LEKSEMA, 3 (1), 11 - 22. https://dx.doi.org/10.22515/ljbs.v3i1.1014

Copyright Holder :

(C) Prastiyono, Y., \& Fahmida, Y., Latief, S. (2021).

First Publication Right :

(C) Anglophile Journal

This article is under:

(ㅇ) (1) (2) 